\title{
Spatial segregation of two species of Mullidae (Mullus surmuletus and M. barbatus) in relation to habitat
}

\author{
Antoni Lombarte ${ }^{1, *}$, Laura Recasens ${ }^{1}$, María González ${ }^{2}$, Luis Gil de Sola ${ }^{2}$ \\ ${ }^{1}$ Institut de Ciències del Mar de Barcelona (CSIC), P. Joan de Borbó, s/n, 08039 Barcelona, Catalonia, Spain \\ ${ }^{2}$ Instituto Español de Oceanografía, Laboratorio de Málaga, Muelle Pesquero, s/n, 29640 Fuengirola, Málaga, Spain
}

\begin{abstract}
The distributions of 2 congenerics, sympatric species of Mullidae (Mullus surmuletus and $M$. barbatus) were studied by means of abundance and length frequencies, obtained in experimental trawl surveys carried out in the springtime (1994 to 1998) throughout the Spanish Mediterranean area. From the data obtained we compared the spatial segregation between these species in relation to the bottom type and to the depth of their habitat. Although $M$. barbatus was the most abundant species throughout the sampling area (except at the shallowest rough-bottom sites), spatial segregation was observed between the 2 species, with the ratio between the species varying according to the bottom type on which they lived. $M$. barbatus showed maximum abundance and frequency on muddy bottoms in waters between 50 and $200 \mathrm{~m}$ deep. For $M$. surmuletus, maximum density and frequency were at a shallower depth (between 10 and $50 \mathrm{~m}$ ) and largely on rough bottoms. At overlap sites, the relative abundance of $M$. barbatus increased on muddy bottoms and decreased on rocky and sandy bottoms. The size frequencies encountered for both species were made up by preadults and adults. Significant size differences between species existed in all the bathymetric strata studied. In all cases, except the more coastal muddy bottom stratum, $M$. surmuletus had a range of sizes and a mean size greater than $M$. barbatus. The structural heterogeneity of the Spanish continental shelf gave rise to a distribution characterised by patches. $M$. barbatus had a clear preference for the areas where the shelf became wider, and $M$. surmuletus was more abundant and frequent in narrow shelf areas.
\end{abstract}

KEY WORDS: Spatial segregation - Size segregation - NW Mediterranean · Mullidae $\cdot$ Mullus barbatus $\cdot$ Mullus surmuletus

Resale or republication not permitted without written consent of the publisher

\section{INTRODUCTION}

Red mullet Mullus barbatus and striped red mullet M. surmuletus are sympatric species with a very similar geographic distribution that includes the coastal areas and the continental shelf of the Mediterranean Sea and the northwestern Atlantic (Hureau 1986). They show common morphological characteristics that differentiate them from other genera of Mullidae, including the arrangement of the teeth (Hureau 1986,

*E-mail: toni@icm.csic.es
Aguirre 1997) and the cephalic musculature and skeleton that determine the head profile characteristic of the genus Mullus (Gosline 1984). They also have common behavioural features, especially relative to feeding, since both species are benthic carnivores. They feed on small invertebrates (crustaceans, molluscs, polychaetes) that live on or within the bottom substrates (Gharbi \& Ktari 1979, Golani \& Galil 1991).

Mullus spp. are major target species of Mediterranean demersal fisheries and are exploited by more than 1 gear type (Stergiou et al. 1992, Reñones et al. 1995, Demestre et al. 1997). Comparative studies of both species have involved age and growth (Bougis 
1952, Gharbi \& Ktari 1981a, Morales-Nin 1986), feeding (Gharbi \& Ktari 1979, Golani \& Galil 1991, Golani 1994, Labropoulou \& Eleftheriou 1997), biological and fishery aspects (Suau \& Vives 1957, Tortonese 1975, Gharbi \& Ktari 1981b, Sánchez et al. 1983, 1995, Reñones et al. 1995), morphological characters (Bougis 1952, Tortonese 1975, Aguirre 1997, Labropoulou \& Eleftheriou 1997, Lombarte \& Aguirre 1997, Aguirre \& Lombarte 1999), and electrophoretical and genetical aspects (Arias \& Morales 1977, Basaglia \& Callegarini 1988, Camarata et al. 1991, Vitturi et al. 1992, Mamuris et al. 1998). Although the different habitat preferences of each species are mentioned in these examinations, quantitative studies of the interspecific differences based on a comparison of abiotic aspects of the ecological niche do not exist, except for Golani (1994), which provides a bathymetric comparison. Furthermore, studies on spatial segregation in fishes are usually limited to small areas, without establishing a connection between geographical distribution and microhabitat or macrohabitat distribution (Munro 1976, Matthews et al. 1992, Gill \& Potter 1993, Golani 1994, Allen \& Baltz 1997, Martins et al. 1998, Platell et al. 1998).

The objective of the present research was to carry out a quantitative study of the distribution and habitat preference of both species. This study of Mullus surmuletus and $M$. barbatus is needed to determine how these 2 congeneric, sympatric species share potential resources and minimise competition (Schoener 1974, Ross 1986). Therefore, the distributions of $M$. surmuletus and $M$. barbatus were compared relative to the bathymetrical and geological characteristics of their respective ecological niches. The distributions of these 2 species were described from data on abundances and size frequencies. These factors have been used in other studies on habitat partitioning of the Mullidae (Munro 1976, Golani 1994, Platell et al. 1998). The present study was conducted in an extensive area of the Spanish western Mediterranean shelf where both species are abundant and co-occur.

\section{MATERIALS AND METHODS}

During MEDITS (Mediterranean International Trawl Survey) cruises undertaken in the springtime, from 1994 to 1998, 392 hauls were conducted in the Iberian Mediterranean, in a sampling area where the genus Mullus is well represented (south of the 41st parallel) (Fig. 1). A GOC 73 trawl (Fiorentini et al. 1999) and an underwater Scanmar system, to measure gear performance, horizontal and vertical net opening, were used. Tow duration was 30 min up to depths of $200 \mathrm{~m}$ and $60 \mathrm{~min}$ in deeper water. For each haul, the numbers of each species were converted into individuals per square kilometre based on horizontal net opening, vessel speed and tow duration.

The abundance and size distributions were obtained for both species. The data were grouped both by depth strata $(10-50,51-100,101-200$ and 201-400 m) and according to the bottom type. The first type considered were muddy bottoms (mud and muddy sands), formed from fine sediments. The second group consisted of rough bottoms (rocks, gravel and coarse sands), formed by heavier sediments than those comprising the previous group. Bottom type was determined from geological maps of the area studied (Rey \& Medialdea 1989) and from macroscopic observation of the sediment in each haul. A high coincidence was found between geological maps and observations in situ; in cases of discrepancy, the macroscopic observation was taken. The number of hauls made, according to depth stratum and bottom type, is indicated in Table 1. For each bottom type and depth stratum, the size distribution was based on the total length of the specimens (calculated to the nearest centimetre) and the abundance expressed as individuals per square kilometre.

Two-way analyses of variance (ANOVA) were used to ascertain whether the abundance between and within each species relative to depth strata and bottom types differed significantly. For ANOVA analyses, data on abundance were normalised using a logarithmic transformation. Additionally, Kolmogorov-Smirnov tests were used to check for inter- and intraspecific differences in the size distributions of both species in relation to environmental factors. The percentage occurrence was calculated based on the percentage of hauls containing each species relative to the total number of hauls made. Pianka's index was calculated to provide a general measurement of niche overlap in the occurrence of species pairs. The overlap estimated by Pianka's index ranged from 0.0 (no overlap) to 1.0 (complete overlap) (Matthews et al. 1982, 1992, Ross 1986).

High-resolution cartographic depictions of fish abundance (expressed as number of individuals caught per square kilometre) were obtained applying a geostatistical kriging model (Matheron 1971, Journel \& Huijbregts 1978). Point kriging was used to estimate red mullet abundance at the nodes of an arbitrarily fine mesh grid over a polygon defined by coastline, depth contours and the sampling points (between 0 and $800 \mathrm{~m}$, and from $5^{\circ} \mathrm{W}$ to $1.5^{\circ} \mathrm{E}$ ). The mesh used in this study was comprised of $101 \times 140$ nodes. The estimated density values at each node $x_{0}$ of the grid were given by

$$
Z^{*}\left(x_{0}\right)=\sum_{i} w_{i} Z\left(x_{i}\right)
$$

where $Z^{*}\left(x_{0}\right)$ the kriging estimate of abundance at each node, was obtained by a linear combination of the samples, each weighed by a factor $\left(w_{i}\right)$, which depen- 
Fig. 1. Location of the sampling sites in the NW Mediterranean, during the MEDITS oceanographic cruises between 1994 and 1998 . (घ) Hauls from rough bottoms between 10 and $400 \mathrm{~m}$; (A) hauls from muddy bottoms between 10 and $400 \mathrm{~m}$; (+) hauls deeper than $401 \mathrm{~m}$, used in the geostatistical kriging modelling

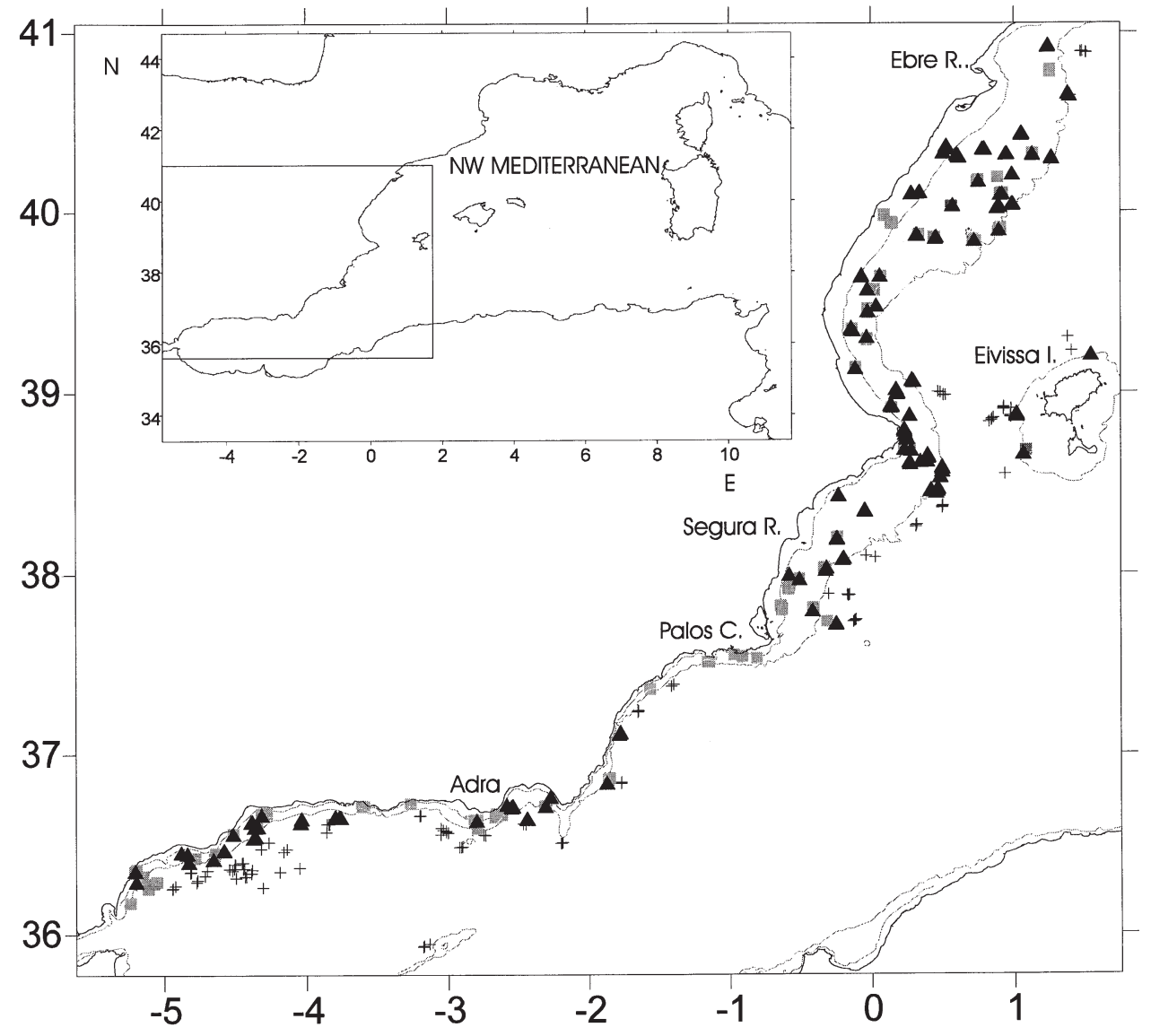

$50 \mathrm{~m}$ ) and the bottoms located below $200 \mathrm{~m}$ (where Mullus barbatus was absent), M. barbatus was always more abundant and occurred more frequently than $M$. surmuletus (Table 1). Clear distribution differences were also observed according to the bottom type. On the muddy bottoms, $M$. barbatus was much more abundant (388.66 ind. $\mathrm{km}^{-2}$ ) and more frequent $(52.10 \%$ of total hauls) than M. surmuletus (42.63 ind. $\mathrm{km}^{-2}$ and $27.72 \%$ ), so that the relationship between both species was approximately 9:1 in favour of $M$. barbatus. The difference between species decreased considerably when the abundances on the rough bottom were compared. In this case, the difference was still significantly in favour of $M$. barbatus (288.60 ind. $\mathrm{km}^{-2}$ ), but the relationship between the species decreased to $2.5: 1$, since the abundance of $M$. surmuletus (116.14 ind. $\mathrm{km}^{-2}$ ) was greater than on muddy bottoms. Similar frequencies between the 2 species $(58.36 \%$ in $M$. barbatus and $59.71 \%$ in $M$. surmuletus) were observed.

The size frequencies encountered for both species ranged between 9 and $25 \mathrm{~cm}$ in Mullus barbatus and 11 and $36 \mathrm{~cm}$ in $M$. surmuletus, representing the preadult and adult population. It was observed that significant size differences existed between species in all depth strata (Table 3). In all cases, $M$. surmuletus, size range and mean size were greater than $M$. barbatus (Table 1, Fig. 2).
Significant interspecific differences existed based on the abundance of the 2 species in relation to the analysed habitat (Table 2). With the exception of the rough bottom in the shallower stratum (between 10 and 
Table 1. Mullus barbatus and M. surmuletus. Characteristics based on sampling hauls in the NW Mediterranean between 1994 and 1998. Size range distribution, mean abundance (ind. $\mathrm{km}^{-2}$ ) and percentage occurrence in relation to total hauls are given according to each bottom type and depth stratum considered

\begin{tabular}{|c|c|c|c|c|c|c|c|}
\hline Bottom & $\begin{array}{l}\text { Depth } \\
\text { (m) }\end{array}$ & $\begin{array}{l}\text { Number } \\
\text { of hauls }\end{array}$ & Species & $\begin{array}{c}\text { Occurrence } \\
(\%)\end{array}$ & $\begin{array}{l}\text { Size range } \\
(\mathrm{cm})\end{array}$ & $\begin{array}{l}\text { Mean size } \\
\quad(\mathrm{cm})\end{array}$ & $\begin{array}{l}\text { Abundance } \\
\text { (ind. } \mathrm{km}^{-2} \text { ) }\end{array}$ \\
\hline \multirow[t]{9}{*}{ Muddy } & \multirow[t]{2}{*}{$10-50$} & \multirow[t]{2}{*}{13} & M. barbatus & 61.54 & $11-20$ & 15.30 & 131.27 \\
\hline & & & M. surmuletus & 7.69 & $15-21$ & 17.70 & 1.32 \\
\hline & \multirow[t]{2}{*}{$51-100$} & \multirow[t]{2}{*}{79} & M. barbatus & 73.42 & $10-24$ & 13.77 & 471.96 \\
\hline & & & M. surmuletus & 46.84 & $13-29$ & 19.12 & 69.03 \\
\hline & \multirow[t]{2}{*}{$101-200$} & \multirow[t]{2}{*}{33} & M. barbatus & 63.64 & $9-24$ & 14.49 & 785.28 \\
\hline & & & M. surmuletus & 48.48 & $14-30$ & 20.07 & 41.38 \\
\hline & $201-400$ & 42 & M. surmuletus & 19.05 & $19-33$ & 23.61 & 6.74 \\
\hline & \multirow[t]{2}{*}{ Total } & \multirow[t]{2}{*}{167} & M. barbatus & 52.10 & $9-24$ & 13.98 & 388.66 \\
\hline & & & M. surmuletus & 37.72 & $13-33$ & 19.54 & 42.63 \\
\hline \multirow[t]{9}{*}{ Rough } & \multirow[t]{2}{*}{$10-50$} & \multirow[t]{2}{*}{26} & M. barbatus & 50.00 & $10-23$ & 14.80 & 114.47 \\
\hline & & & M. surmuletus & 65.38 & $11-27$ & 16.47 & 146.46 \\
\hline & \multirow[t]{2}{*}{$51-100$} & \multirow[t]{2}{*}{46} & M. barbatus & 73.91 & $9-24$ & 14.69 & 561.48 \\
\hline & & & M. surmuletus & 56.52 & $11-32$ & 17.82 & 118.61 \\
\hline & \multirow[t]{2}{*}{$101-200$} & \multirow[t]{2}{*}{30} & M. barbatus & 60.00 & $11-25$ & 16.08 & 117.30 \\
\hline & & & M. surmuletus & 53.33 & $12-36$ & 20.79 & 102.76 \\
\hline & $201-400$ & 10 & M. surmuletus & 30.00 & $20-30$ & 26.25 & 4.09 \\
\hline & \multirow[t]{2}{*}{ Total } & \multirow[t]{2}{*}{112} & M. barbatus & 58.36 & $9-25$ & 14.79 & 288.60 \\
\hline & & & M. surmuletus & 59.71 & $11-36$ & 17.90 & 116.14 \\
\hline
\end{tabular}

The spatial overlap indices between Mullus barbatus and $M$. surmuletus, for all strata and bottom types studied, were between 0.34 and 0.42 (Table 4), except in the shallow muddy bottom stratum, where the Pianka index was very low (0.14). The abundance and the size distributions in the hauls where both species co-existed did not differ substantially from those observed in total hauls.

\section{Intraspecific variability}

The 2-way ANOVAs indicated the existence of significant differences in abundance within each species in relation to the factors analysed (Table 5). In Mullus bar-

Table 2. Snedecor-Fisher's $F$ for a 2-way ANOVA of the interspecific abundances (ind. $\mathrm{km}^{-2}$ ) of Mullus barbatus and $M$. surmuletus in relation to bottom type and depth of sampling hauls in the Spanish NW Mediterranean between 1994 and 1998. *Significant values of $F(\mathrm{p}<0.05)$

\begin{tabular}{|lccc|}
\hline \multicolumn{2}{|c}{ Factors } & Interaction & df error \\
Species & Bottom & Species $\times$ Bottom & \\
\hline $15.61^{*}$ & $11.17^{*}$ & 0.38 & 554 \\
Species & Depth & Species $\times$ Depth & \\
\hline $10.90^{*}$ & $38.89^{*}$ & $6.29^{*}$ & 550 \\
\hline
\end{tabular}

batus, significant differences were observed in relation to depth, since they were considerably more abundant in waters between 51 and 200 m deep, especially on muddy bottoms, where they had a density of 785.28 ind. $\mathrm{km}^{-2}$. In the case of $M$. surmuletus, significant differences were observed in relation to the substratum; this species was more abundant on the rough bottom (116.14 ind. $\mathrm{km}^{-2}$ ) than on the muddy one (42.63 ind. $\mathrm{km}^{-2}$ ). For M. surmuletus significant differences were also detected in rela-

Table 3. Kolmogorov-Smirnov distance $(d)$ for the comparison of size frequencies between Mullus barbatus and M. surmuletus based on the substratum. ${ }^{*}$ Significant values of $d$ $(\mathrm{p}<0.05)$

\begin{tabular}{|c|c|c|c|c|}
\hline \multicolumn{5}{|c|}{ (a) Interspecific comparisons } \\
\hline Depth (m) & \multicolumn{2}{|c|}{ Muddy } & \multicolumn{2}{|c|}{ Rough } \\
\hline $10-50$ & \multicolumn{2}{|c|}{$0.46^{*}$} & \multicolumn{2}{|c|}{$0.31^{*}$} \\
\hline $51-100$ & \multicolumn{2}{|c|}{$0.66^{*}$} & \multicolumn{2}{|c|}{$0.41^{*}$} \\
\hline $101-200$ & \multicolumn{2}{|c|}{$0.74^{*}$} & \multicolumn{2}{|c|}{$0.47^{*}$} \\
\hline \multicolumn{5}{|c|}{ (b) Intraspecific comparisons } \\
\hline & \multicolumn{2}{|c|}{ Muddy } & \multicolumn{2}{|c|}{ Rough } \\
\hline Depth (m) & $51-100$ & $101-200$ & $51-100$ & $101-200$ \\
\hline \multicolumn{5}{|c|}{ M. barbatus } \\
\hline $10-50$ & $0.39^{*}$ & $0.26^{*}$ & 0.07 & 0.23 \\
\hline $51-100$ & - & 0.19 & - & $0.29^{*}$ \\
\hline \multicolumn{5}{|c|}{ M. surmuletus } \\
\hline $10-50$ & 0.24 & $0.40^{*}$ & 0.22 & $0.49^{*}$ \\
\hline $51-100$ & - & 0.16 & - & $0.32^{*}$ \\
\hline
\end{tabular}


muddy bottom rough bottom
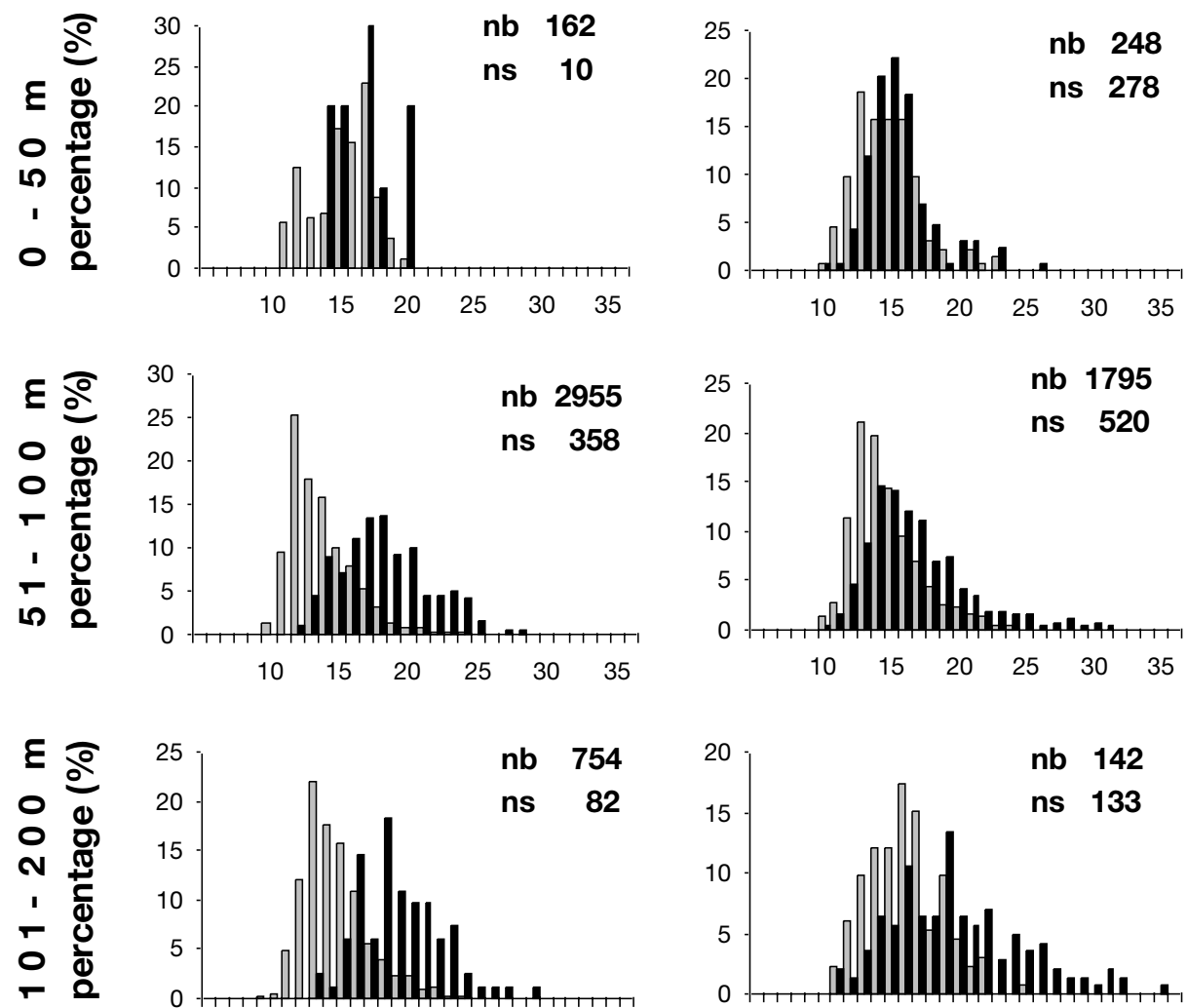

nb $\quad 754$
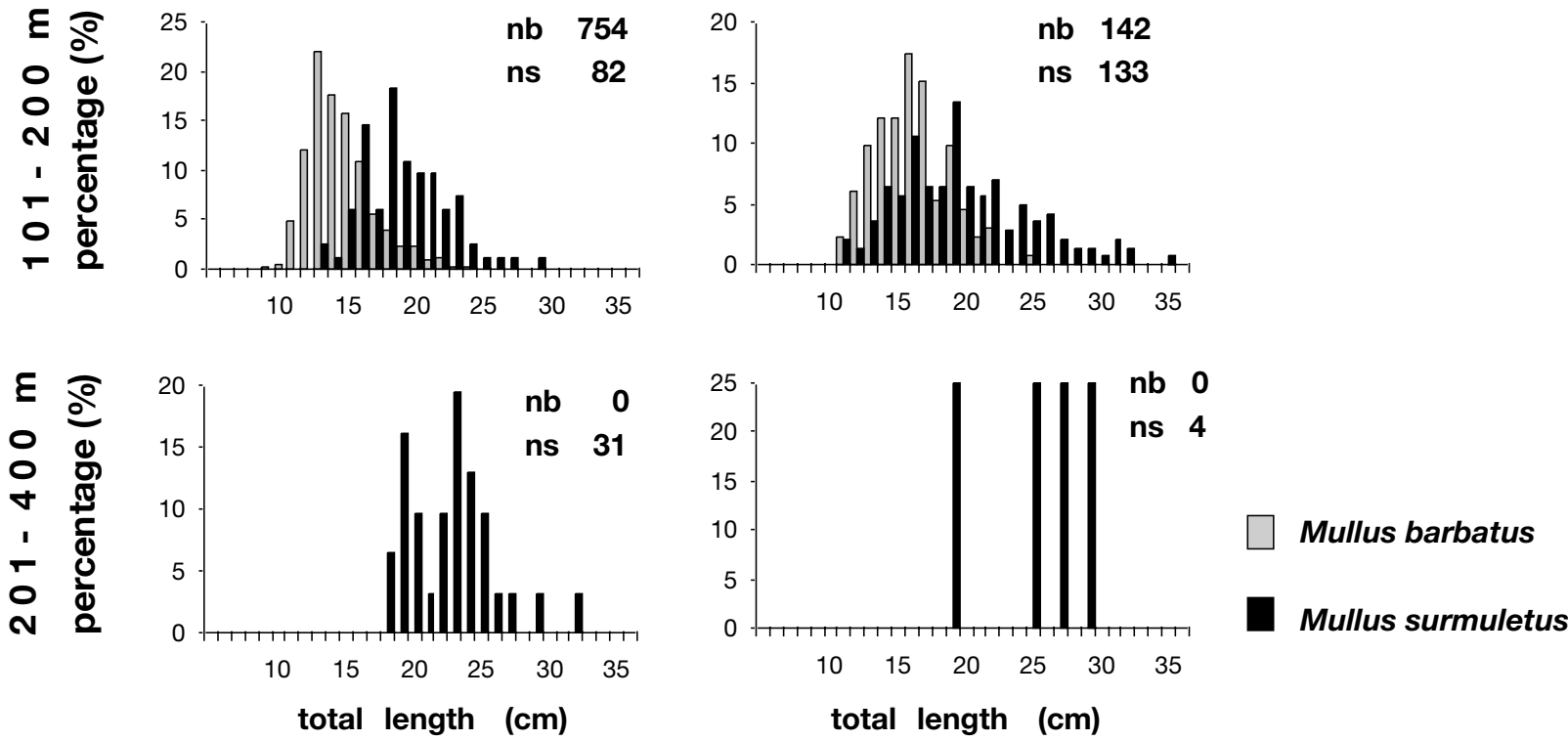

Fig. 2. Size frequencies by stratum and bottom type expressed as a percentage. nb: number of Mullus barbatus individuals; ns: number of $M$. surmuletus individuals

tion to depth; maximum abundances were located close to the coast, in shallower waters (Table 1).

Regarding the size compositions, significant differences were seen within each species according to substrate and to depth (Tables 1 \& 3b, Fig. 2). In both species, a size increase was observed in relation to depth, with the exception of the specimens of Mullus barbatus from muddy bottoms in the 10 and $50 \mathrm{~m}$ depth strata. The size increases in relation to depth were more evident for $M$. surmuletus, especially those living on rough bottoms. With regard to substratum type, the intraspe- cific comparison of the size distributions revealed that the smaller sized individuals were concentrated in a different way. $M$. barbatus were on the muddy bottoms and $M$. surmuletus on the rough bottoms (Fig. 2).

\section{Geographical distribution}

Clear differences were observed in the distribution of the 2 species in the Iberian Mediterranean (Figs. 3 \& 4). Although Mullus barbatus was the most 

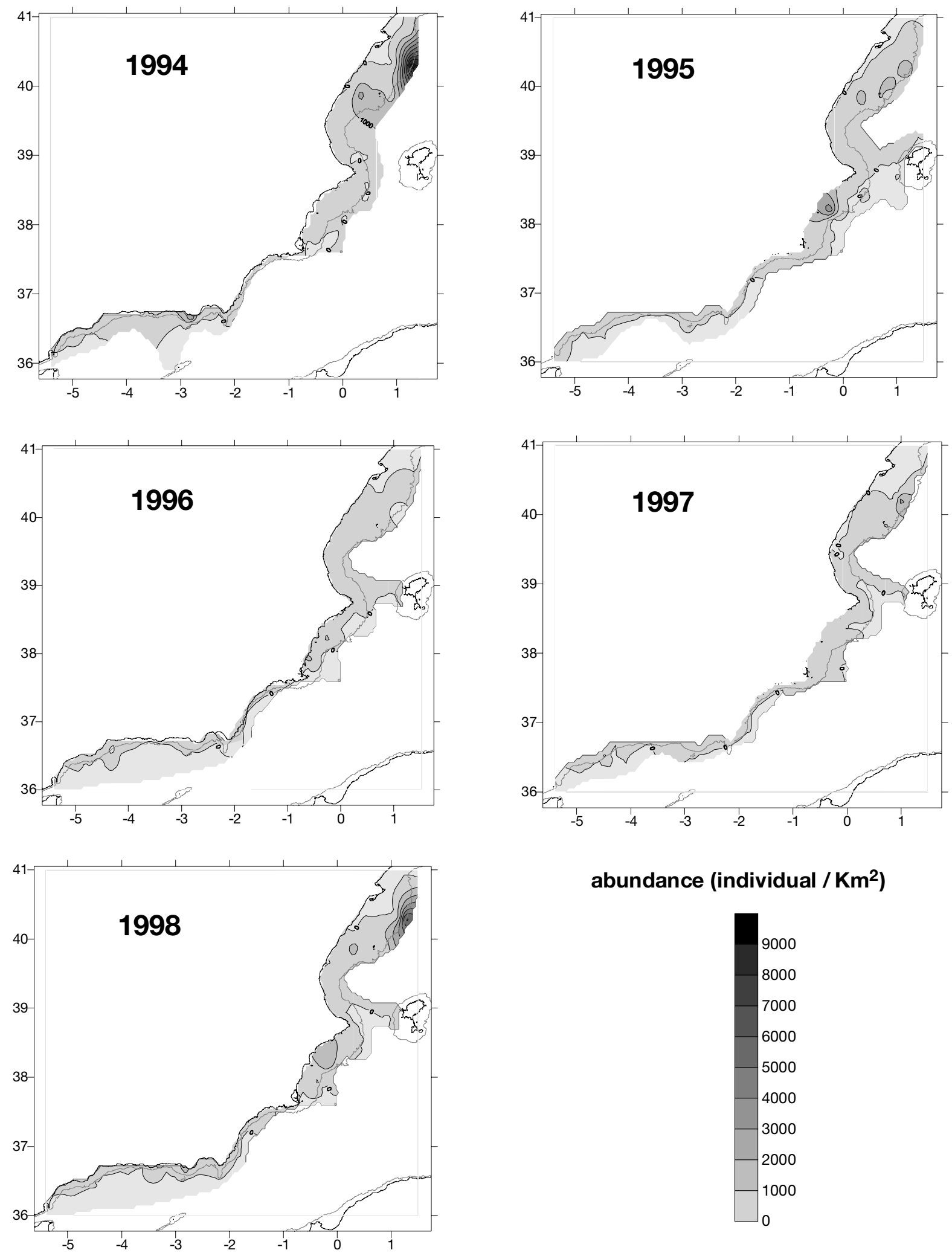

abundance (individual / $\mathrm{Km}^{2}$ )

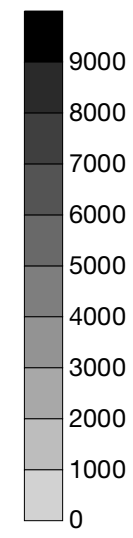

Fig. 3. Geographical distribution of Mullus barbatus based on abundance (ind. $\mathrm{km}^{-2}$ ) along the continental shelf of the Iberian peninsula between 1994 and 1998 

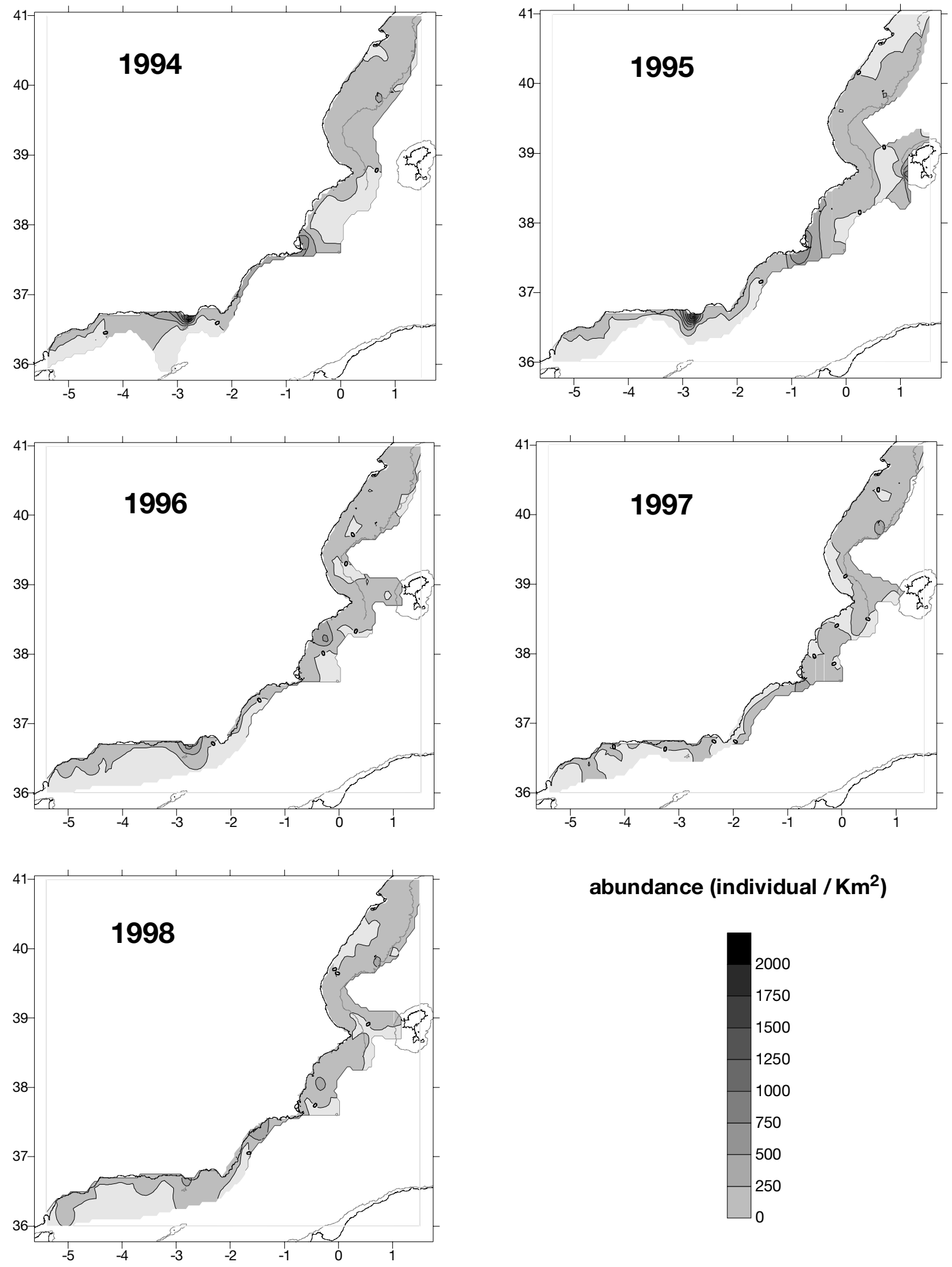

abundance (individual $/ \mathrm{Km}^{2}$ )

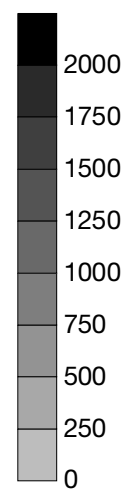

Fig. 4. Geographical distribution of Mullus surmuletus based on abundance (ind. $\mathrm{km}^{-2}$ ) along the continental shelf of the Iberian peninsula between 1994 and 1998 
Table 4. Pianka's overlap index between Mullus barbatus and $M$. surmuletus in relation to the spatial distribution of both species in the (NW Mediterranean between 1994 and 1998

\begin{tabular}{|lcc|}
\hline Bottom & Depth $(\mathrm{m})$ & Overlap index \\
\hline Muddy & $0-50$ & 0.14 \\
& $51-100$ & 0.38 \\
& $101-200$ & 0.38 \\
& Total & 0.34 \\
Rough & $0-50$ & 0.42 \\
& $51-100$ & 0.35 \\
& $101-200$ & 0.34 \\
& Total & 0.37 \\
\hline
\end{tabular}

abundant species throughout the sampling area, its density was especially high at sites characterised by a wider continental shelf, e.g. at the mouth of the Ebre River and, to a lesser degree, at the mouth of the Segura River. M. surmuletus showed a different pattern, being more abundant in areas characterised by a narrow continental shelf, such as the island of Eivissa, Palos Cape and the Adra area (Fig. 1). For both species, these areas of maximum abundance were very consistent throughout the period studied. However, among years, strong intraspecific variations were seen in the intensity of these abundances. For M. barbatus, maximum abundances were registered in 1994 and 1998, while for $M$. surmuletus the maxima were observed in 1994 and 1995.

\section{DISCUSSION}

Niche differentiation can be caused by a number of different factors, such as the allocation of resources, microhabitat or prey species, and spatial or temporal segregation. This is also the case for the 2 studied species, Mullus barbatus and M. surmuletus. Pianka's overlap index ( $<0.40$ in most of the strata) indicates a partial differentiation in habitat use (Ross 1986, Mathews et al. 1992) corresponding to the bathymetric distribution and a preference for a particular substratum type.

Although Mullus surmuletus has a wider bathymetric range (occurring to a depth of $400 \mathrm{~m}$ ) than $M$. barbatus, its abundance maxima are concentrated near the coast, in the stratum between 10 and $100 \mathrm{~m}$, and especially in areas where the shelf is steepest. In the western Mediterranean M. surmuletus appears either as the only species on hard, sandy bottoms or with marine phanerogams (seagrasses) from coastal waters (between 0 and $30 \mathrm{~m}$ ) (Dufour et al. 1995, GarcíaRubies \& Macpherson 1995). With increases in the depth of the habitat $M$. surmuletus density decreases considerably, and is very low on the lower part of the slope (between 201 and $400 \mathrm{~m}$ ). M. barbatus shows a more limited bathymetric distribution than $M$. surmuletus (it never occurs below $200 \mathrm{~m}$ ), but it has much greater densities in the middle strata of the shelf (between 51 and $200 \mathrm{~m}$ on muddy bottoms and between 51 and $100 \mathrm{~m}$ on rough bottoms). The observed bathymetric segregation is similar to that of previous comparative studies along the Catalan coast (Sánchez et al. 1983), in Israel (Golani \& Galil 1991, Golani 1994) and off the Island of Mallorca (Reñones et al. 1995). This tendency for bathymetric habitat partitioning has been observed in other congeneric Mullidae (goatfishes) in Australian waters (McCormick 1995, Platell et al. 1998). In addition, both species show clear niche segregation in relation to the bottom type that constitutes their selected habitat (Margalef 1980, Hureau 1986). M. surmuletus shows a clear preference for rough bottoms, while $M$. barbatus has a greater abundance on muddy bottoms. This difference in substrate preference is especially marked in young individuals, and is coincident with the distribution of larvae and the juvenile settlement areas observed in the Catalan Sea (NW Mediterranean) (Sabatés \& Palomera 1987, GarcíaRubies \& Macpherson 1995).

Other factors leading to niche separation, for example food resources, are much less evident, as occurs in animals feeding on relatively small food items (Schoener 1974). In the shallow waters of Iraklion Bay (Greece, E Mediterranean), Labropoulou \& Eleftheriou (1997) observed food niche segregation in relation to prey taxa. Mullus barbatus showed a preference for Polychaeta and $M$. surmuletus for brachyuran Crustacea. However, in other studies the degree of diet overlap observed in relation to taxa and prey size is much higher (Golani \& Gail 1991, Golani 1994). Further, the availability of different resources may be separated in time, especially in the first phases of life. The 2 studied species show a clear temporal segregation of spawning period (Sabatés \& Palomera 1987, Sabatés 1988, Sánchez et al. 1995).

The other major stimulus to niche separation could be environmental conditions. Two species may utilise a similar resource, but if they respond differently to different environmental conditions, each may be competi-

Table 5. Snedecor-Fisher's $F$ for a 2-way ANOVA of the intraspecific abundances (ind. $\mathrm{km}^{-2}$ ) of Mullus barbatus and $M$. surmuletus in relation to bottom type and depth of sampling hauls in the NW Mediterranean between 1994 and 1998. ${ }^{*}$ Significant values of $F(\mathrm{p}<0.05)$

\begin{tabular}{|lcrcc|}
\hline Species & \multicolumn{2}{c}{ Factors } & $\begin{array}{c}\text { Interaction } \\
\text { Bottom }\end{array}$ & df error \\
& & & Bottom $\times$ Depth & \\
\hline M. barbatus & 0.14 & $25.99^{*}$ & 1.08 & 271 \\
M. surmuletus & $7.53^{*}$ & $6.50^{*}$ & 1.49 & 271 \\
\hline
\end{tabular}


tively superior in different environments (Begon 1990, Norton et al. 1995). This possibility is closely related to the differentiated sensory capabilities of both species. Ecomorphological studies show that in the chemoreceptor system of Mullus barbatus the taste buds of its hyoidal barbels are more developed than those in the system of M. surmuletus (Lombarte \& Aguirre 1997). In benthivorous fish species, this morphological characteristic is associated with species that live in waters with a reduced visual field, e.g. in muddy or deeper waters (Gomahr et al. 1992). On the other hand, M. surmuletus shows a larger S:O ratio (sensory area versus otolith area) in the sagitta otolith of the inner ear than does $M$. barbatus (Aguirre \& Lombarte 1999). The increase of the $\mathrm{S}: \mathrm{O}$ ratio is associated with an increase in hearing sensitivity (Gauldie 1988, Lombarte 1992, Arellano et al. 1995) and with relatively noisy environments, such as reefs or inshore waters (Rogers \& Cox 1988).

Segregation of both species in relation to size has also been noted. The size differences according to depth observed among congeneric, sympatric species of teleost fishes and other zoological groups, such as in Crustacea, have been related to increases in prey size in parallel with increases in the size of the predator (Eggold \& Motta 1992, Company \& Sardà 1997, Labropoulou \& Eleftheriou 1997), thus producing interspecific food niche segregation based on the size of the prey. However, for the genus Mullus no such relationship exists between the individual's size and that of its prey (Golani 1994, Labropoulou \& Eleftheriou 1997), which means that size-prey partitioning can be discarded as a mechanism for explaining differencies in interspecific size. It is also possible to explain size segregation in relation to the increase in the number of taste buds and the adjacent innervation in larger individuals (Lombarte \& Aguirre 1997). Some sensory abilities of adults, especially those connected with discrimination and location, are improved in this manner through the continuous addition of sensory cells (Popper et al. 1988, Lombarte \& Popper 1994). According to the sensorial hypothesis, the greater sensitivity in larger individuals could explain the wider distribution range of $M$. surmuletus and its competitive edge over smaller $M$. barbatus individuals.

The observed niche segregation covers a larger geographical range; in the successive years studied, a homogeneous distribution was never observed in the study area. Maximum abundances corresponded to certain geological characteristics, such as the structure of the shelf. Accordingly, the structural heterogeneity of the Iberian peninsula continental shelf (Rey \& Medialdea 1989) gave rise to a characteristic distribution of patches; the geographical location of these patches remained stable throughout the period studied. This result is especially notable since the spatial segrega- tion among congeneric species has not previously been studied in such an extensive latitudinal range. Therefore, it was observed that Mullus barbatus showed a clear preference for the areas where the shelf becomes wider. On the contrary, $M$. surmuletus showed a clear preference for narrow shelf areas with rocky or sandy bottoms.

Research on how similar species divide resources helps to interpret the natural regulation of species diversity (Schoener 1974) and speciation processes (Rifcklefs \& Miles 1994). Our results suggest that both sympatric Mullus species have evolved by partially segregating their ecological niches, thus avoiding competition. $M$. surmuletus and $M$. barbatus have very similar feeding habits (Gharbi \& Ktari 1979, Golani \& Galil 1991, Golani 1994), but their ecological niches show a high degree of environmental segregation and partial spatial and geographical segregation, related to the type of bottom and the bathymetric distribution.

Genetic, morphological and ecological data suggest that Mullus barbatus is a species of more recent origin than $M$. surmuletus. The very close genetic distance between $M$. barbatus and M. surmuletus (Basaglia \& Callegarini 1988, Camarata et al. 1991, Vitturi et al. 1992, Mamuris et al. 1998), and a lower intraspecific genetic variability in $M$. barbatus compared with $M$. surmuletus (Mamuris et al. 1998) would corroborate this hypothesis. Furthermore, although M. barbatus shares the common features that define the genus Mullus, it has apomorphic characteristics in its barbels and in the development of the cephalic muscles (Gosline 1984, Lombarte \& Aguirre 1997) that allow it to exploit resources from muddy and turbid bottoms with remarkable success. This contrasts with the rest of the members of the Mullidae family (Lombarte \& Aguirre 1997), which have a preference for coastal ecological niches and harder substrates (Munro 1976, Gosline 1984, McCormick 1993, 1995, Golani 1994, Platell et al. 1998).

Acknowledgements. This work was supported by the MEDITS project in Spain. We are grateful to the persons who participated in MEDITS-ES research cruises.

\section{LITERATURE CITED}

Aguirre H (1997) Presence of dentition in the premaxilla of juvenile Mullus barbatus and M. surmuletus. J Fish Biol 51:1186-1191

Aguirre H, Lombarte A (1999) Ecomorphologic comparisons of sagittae in Mullus barbatus and M. surmuletus. J Fish Biol 55:105-114

Allen RI, Baltz DM (1997) Distribution and microhabitat use by flatfishes in a Louisiana estuary. Environ Biol Fishes 50:85-103 
Arellano RV, Hamerlynck O, Vincs M, Mees J, Hostens K, Gijselinck W (1995) Changes in the ratio of the sulcus acusticus area to the sagitta area of Pomatochistus minutus and P. lozanoi (Pisces, Gobiidae). Mar Biol 122:355-360

Arias E, Morales E (1977) Estudio comparativo de los electroferogramas de las proteínas musculares solubles de Mullus barbatus y Mullus surmuletus. Invest Pesq 41:323-330

Basaglia F, Callegarini C (1988) Biochemical characteristics of red mullet of the central Mediterranean. Comp Biochem Physiol 89:731-736

Begon M, Harper JL, Townsend CR (1990) Ecology: individuals, populations and communities. Blackwell Scientific Publications, Cambridge, MA

Bougis P (1952) Recherches biométriques sur les rougets (Mullus barbatus L., Mullus surmuletus, L.). Arch Zool Exp Gén 89:57-174

Camarata M, Parrinello N, Arculeo M (1991) Biochemical taxonomic differentiation between Mullus barbatus and Mullus surmuletus (Pisces, Mullidae). Comp Biochem Physiol 99:719-722

Company JB, Sardá F (1997) Reproductive patterns and population characteristics in five deep-water pandalid shrimps in the western Mediterranean along a depth gradient (150-1100 m). Mar Ecol Prog Ser 148:49-58

Demestre M, Sbrana M, Alvarez F, Sánchez P (1997) Analysis of the interaction of fishing gear in Mullus barbatus fisheries of the western Mediterranean. J Appl Ichthyol 13: 49-56

Dufour V, Jouvenel JY, Galzin R (1995) Study of a Mediterranean reef fish assemblage. Comparisons of population distributions between depths in protected and unprotected areas over one decade. Aquat Living Resour 8:17-25

Eggold BT, Motta PJ (1992) Ontogenetic dietary shifts and morphological correlates in striped mullet, Mugil cephalus. Environ Biol Fishes 34:139-158

Fiorentini L, Dremière PY, Leoniri I, Sala A, Palumbo V (1999) Efficiency of the bottom trawl used for the Mediterranean international trawl survey (MEDITS). Aquat Living Resour 12:187-205

García-Rubies A, Macpherson E (1995) Substrate use and temporal pattern of recruitment in juvenile fishes of the Mediterranean littoral. Mar Biol 124:35-42

Gauldie WA (1988) Function, form and time-keeping properties of fish otoliths. Comp Biochem Physiol 91:395-402

Gharbi H, Ktari MH (1979) Régime alimentaire des rougets (Mullus barbatus Linnaeus, 1758 et Mullus surmuletus Linnaeus, 1758) du golfe de Tunis. Bull Inst Natl Sci Tech Océanogr Pêche Salammbô 6:41-52

Gharbi H, Ktari MH (1981a) Croissance des rougets en Tunisie. Bull Inst Natl Sci Tech Océanogr Pêche Salammbô 8:5-40

Gharbi H, Ktari MH (1981b) Biologie de Mullus barbatus Linnaeus, 1758 et Mullus surmuletus Linnaeus, 1758 (poissons, téléostéens, mullidés) des côtes tunisiennes, taille et âge de première maturité sexuelle, cycle sexuel et coefficient de condition. Bull Inst Natl Sci Tech Océanogr Pêche Salammbô 8:41-51

Gill HS, Potter IC (1993) Spatial segregation amongst goby species within an Australian estuary, with a comparison of the diets and salinity tolerance of the two most abundant species. Mar Biol 117:515-526

Golani D (1994) Niche separation between colonizing and indigenous goatfish (Mullidae) along the Mediterranean coast of Israel. J Fish Biol 45:503-513

Golani D, Galil B (1991) Trophic relationship of colonizing and indigenous goatfishes (Mullidae) in the eastern Mediterranean with special emphasis on decapod crustaceans. Hydrobiologia 21:27-33
Gomahr A, Palzenberger MM, Kotrschal K (1992) Density and distribution of external taste buds in cyprinids. Environ Biol Fishes 33:125-134

Gosline WA (1984) Structure, function and ecology in the goatfishes (Family Mullidae). Pac Sci 38:312-323

Hureau JC (1986) Mullidae. In: Whitehead PJP, Bauchot ML, Hureau JC, Nielsen J, Tortonese E (eds) Fishes of the northeastern Atlantic and the Mediterranean. UNESCO, Paris, p 877-882

Journel AG, Huijbregts CJ (1978) Mining geostatistics. Academic Press, New York

Labropoulou M, Eleftheriou A (1997) The foraging ecology of two pairs of congeneric demersal fish species: importance of morphological characteristics in prey selection. J Fish Biol 50:324-340

Lombarte A (1992) Changes in otolith area: sensory area ratio with body size and depth. Environ Biol Fishes 33:405-410

Lombarte A, Aguirre H (1997) Quantitative differences in the chemoreceptor systems in the barbels of two species of Mullidae (Mullus surmuletus and M. barbatus) with different bottom habitats. Mar Ecol Prog Ser 150:57-64

Lombarte A, Popper AN (1994) Quantitative analyses of postembryonic hair cell addition in the otolithic endorgans of the inner ear of the European hake, Merluccius merluccius (Gadiformes, Teleostei). J Comp Neurol 345:419-428

Mamuris Z, Apostolidis AP, Triantaphyllidis C (1998) Genetic protein variation in red mullet (Mullus barbatus) and striped red mullet ( $M$. surmuletus) populations from the Mediterranean Sea. Mar Biol 130:353-360

Margalef R (1980) Ecología. Omega, Barcelona

Martins MJ, Collares-Pereira MJ, Cowx IG, Coelho MM (1998) Diploids versus triploids of Rutilus alburnoides: spatial segregation and morphological differences. J Fish Biol 52:817-828

Matheron G (1971) The theory of regionalized variables and its applications. Les Cahiers du Centre de Morphologie Mathématique, fasc. 5. Ecole Nationale Supérieure de Mines de Paris, Paris

Matthews WJ, Beck J, Surat E (1982) Comparative ecology of the darters Etheostoma podostomone, E. flabellare and Percina roanoka in the upper Roanoke River drainage, Virginia. Copeia 1982:805-814

Matthews WJ, Gelwick FP, Hoover JJ (1992) Food of and habitat use by juveniles of species of Micropterus and Morone in a southwestern reservoir. Trans Am Fish Soc 121:54-66

McCormick MI (1993) Development and changes at settlement in the barbel structure of the reef fish, Upeneus tragula (Mullidae). Environ Biol Fishes 37:269-282

McCormick MI (1995) Fish feeding on mobile benthic invertebrates: influence of spatial variability in habitat associations. Mar Biol 121:627-637

Morales-Nin B (1986) Age and growth of Mullus barbatus and M. surmuletus from the Catalan Sea. Rapp P-V Réun Comm Int Explor Sci Mer Méditerr Monaco 10:232

Munro JL (1976) Aspects of the biology and ecology of Caribbean reef fishes: Mullidae (goat-fishes). J Fish Biol 9:79-97

Norton SF, Luczkovich JL, Motta PJ (1995) The role of ecomorphological studies in the comparative biology of fishes. Environ Biol Fishes 44:287-304

Platell ME, Potter IC, Clarke KR (1998) Do the habitats, mouth morphology and diets of the mullids Upeneichthys stotti and $U$. lineatus in coastal waters of southeastern Australia differ? J Fish Biol 52:398-418

Popper AN, Rogers PH, Saidel WM, Cox M (1988) Role of the fish ear in sound processing. In: Atema J, Fay RR, Popper AN, Tavolga WN (eds) Sensory biology of aquatic animals. 
Springer-Verlag, New York, p 687-710

Reñones O, Massuti E, Morales-Nin B (1995) Life history of the red mullet Mullus surmuletus from the bottom-trawl fishery off the Island of Majorca (north-west Mediterranean). Mar Biol 123:411-419

Rey JJ, Medialdea T (1989) Los sedimentos cuaternarios superficiales del margen continental español. Publ Espec Inst Esp Oceanogr 3:1-29

Rifckles RE, Miles DB (1994) Ecological and evolutionary inferences from morphology: an ecological perspective. In: Wainwright PC, Reilly SM (eds) Ecological morphology: integrative organismal biology. University of Chicago Press, Chicago, p 13-41

Rogers PH, Cox M (1988) Underwater sound as a biological stimulus. In: Atema J, Fay RR, Popper AN, Tavolga WN (eds) Sensory biology of aquatic animals. Springer-Verlag, New York, p 687-710

Ross ST (1986) Resource partitioning in fish assemblages: a review of field studies. Copeia 1986:352-388

Sabatés A (1988) Sistemática y distribución espacio-temporal del ictioplancton en la costa catalana. PhD thesis, University of Barcelona

Sabatés A, Palomera I (1987) Repartition des larves du rouget

Editorial responsibility: Otto Kinne (Editor),

Oldendorf/Luhe, Germany de vase (Mullus barbatus, L., 1758) le long de la côte catalane (Méditerranée occidentale). Vie Milieu 37:207-214

Sánchez P, Morales-Nin B, Martín P (1983) The mullets (Mullus surmuletus L., 1758, Mullus barbatus L., 1758) of the Catalan coast: biological and fishing aspects. Int Counc Explor Sea Comm Meet (Demersal Fish Comm) G:27:1-19 Sánchez P, Alvarez F, de Ranieri S, Sartor P (1995) Evaluation and analysis of the interaction of fishing gears in the demersal fisheries of western Mediterranean. Final report, EC DGXIV (FAIR program) (mimeo)

Schoener TW (1974) Resource partitioning in ecological communities. Science 1985:27-39

Stergiou KI, Petrakis G, Papaconstantinou C (1992) The Mullidae (Mullus barbatus, M. surmuletus) fishery in Greek waters, 1964-1986. FAO Fish Rep 477:97-113

Suau P, Vives F (1957) Contribución al estudio del salmonete de fango (Mullus barbatus L.) del Mediterráneo occidental. Invest Pesq 9:97-118

Tortonese E (1975) Fauna d'Italia.'Osteichtyes'. Pesci Osse, Vol XI. Edizioni Calderini, Bologna, p 133-139

Vitturi R, Catalano E, Barbieri R (1992) Karyological and molecular characterization of Mullus surmuletus and Mullus barbatus (Pisces, Mullidae). Cytologia (Tokyo) 57:65-74

Submitted: December 13, 1999; Accepted: May 11, 2000

Proofs received from author(s): October 11, 2000 